Vol. 4, No. 1, 2021

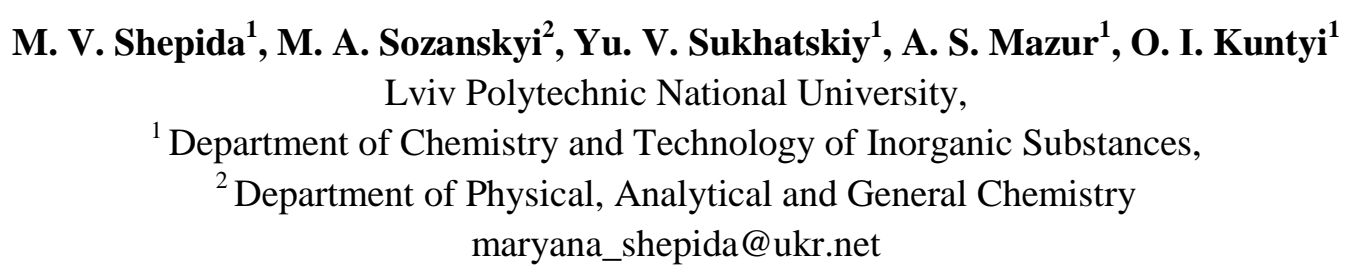

\title{
SONOELECTROCHEMICAL SYNTHESIS OF SILVER NANOPARTICLES IN POLYVINYLPYRROLIDONE SOLUTIONS
}

https://doi.org/ 10.23939/ctas2021.01.082

The results of investigations of the influence of main parameters (surfactant concentration and temperature) on the synthesis of silver nanoparticles (AgNPs) by the sonoelectrochemical method in polyvinylpyrrolidone (PVP) solutions by cyclic voltammetry (CVA) are presented. It is shown that the ultrasonic field $(22 \mathrm{kHz}$ ) leads to an increase in the anodic and cathodic currents by $\sim 30 \%$. A scheme of the AgNPs formation has been proposed, which includes the following main processes: 1) dissolution of sacrificial silver anodes at $E=0.2 \ldots 1.0 \mathrm{~V}$ with the formation of $[\mathrm{AgPVP}]^{+}$complex ions; 2) cathodic and sonochemical reduction of the latter to $\left.\operatorname{Ag}(0) ; 3\right)$ formation of AgNPs. It has been established that with an increase in PVP concentration from 1 to $4 \mathrm{~g} \cdot \mathrm{L}^{-1}$, the anodic and cathodic currents decrease by 40-60\%. The formation rate of AgNPs also decreases. The growth of anodic and cathodic currents and the formation rate of nanoparticles in the range of $20 \ldots 60{ }^{\circ} \mathrm{C}$ corresponds to the diffusion-kinetic action of the temperature factor. The CVA curves practically do not change in time, which indicates the stability of anodic and cathodic processes at prolonged sonoelectrochemical synthesis. The character of the UV-Vis spectra of AgNPs colloidal solutions in PVP with the $405 \ldots 410 \mathrm{~nm}$ absorption maximum is the same in a wide range of nanoparticle concentrations.

Key words: sonoelectrochemical synthesis; silver nanoparticles; polyvinylpyrrolidone; sacrificial anodes; cyclic voltammetry; "green" synthesis.

\section{Introduction}

Sonoelectrochemical synthesis of metal nanoparticles (MNPs) is one of the promising methods, which is characterized by a high rate of processes, the purity of obtained products and economy [1-5]. By using non-toxic surfactants as stabilizers for MNPs, it also meets the requirements of "green" technologies. In the literature [6-11], the synthesis of AgNPs has been described, where nonstationary electrolysis is mainly used. The latter make up conditions for the realization of the algorithm in chain of the following main processes: 1) reduction of $\mathrm{Ag}(+)$ to $\mathrm{Ag}(\mathrm{O}) \rightarrow$ 2) nucleation $\rightarrow$ 3) nuclei growth with the AgNPs formation. During sonoelectrochemical synthesis in surfactant aqueous solutions, the first process includes cathodic reduction (1) and radicals reduction, in particular $\mathrm{H} \cdot \mathrm{R} \cdot$, due to (2)-(5) reactions [12]. Thus, the $\operatorname{Ag}(+)$ concentration in solution is one of the factors providing the AgNPs synthesis algorithm.

$$
\begin{gathered}
\mathrm{Ag}^{+}+\mathbf{e} \rightarrow \mathrm{Ag} \\
\left.\mathrm{H}_{2} \mathrm{O}\right) \rightarrow \cdot \mathrm{H}+\cdot \mathrm{OH} \\
\mathrm{RH}+\cdot \mathrm{OH}(\cdot \mathrm{H}) \stackrel{)}{\rightarrow} \mathrm{R} \cdot+\mathrm{H}_{2} \mathrm{O}\left(\mathrm{H}_{2}\right) \\
\mathrm{Ag}^{+}+\cdot \mathrm{H} \rightarrow \mathrm{Ag}+\mathrm{H}^{+} \\
\mathrm{Ag}^{+}+\cdot \mathrm{R} \rightarrow \mathrm{Ag}+\mathrm{R}^{\prime}+\mathrm{H}^{+}
\end{gathered}
$$

Most of the known sonoelectrochemical synthesis methods of AgNPs are based on the use of $\mathrm{AgNO}_{3}[6,7], \mathrm{Ag}_{3} \mathrm{C}_{6} \mathrm{H}_{5} \mathrm{O}_{7}$ [8], $\mathrm{AgClO}_{4}$ [10] salts as precursors of $\mathrm{Ag}(+)$ ions. However, it is difficult to ensure their stable concentration and, accordingly, 


\section{Sonoelectrochemical synthesis of silver nanoparticles in polyvinylpyrrolidone solutions}

the algorithm of the $(1,4,5)$ recovery processes. This causes the AgNPs design problem, which is preferred in modern nanotechnology. That's because, the geometry of MNPs is the main parameter of their functional properties $[13,14]$. The sacrificial silver anodes are increasingly used to provide the concentration stability of $\operatorname{Ag}(+)$ ions [9, 11, 15-17]. The latter, in addition, reduce the number of components of the reaction medium. However, it has been little described in the literature about the mutual influence of the sonoelectrochemical synthesis parameters and the nature of surfactant on the formation of solutions of metal nanoparticles. This restrains the creation of the theoretical foundations of such method and, accordingly, hinders its applied use.

The proposed study was aimed at investigating the "green" synthesis of AgNPs in polyvinylpyrrolidone (PVP) solutions by the sonoelectrochemical method using silver sacrificial anodes.

PVP is a non-toxic polymeric surfactant, which is used as an effective stabilizer of silver nanoparticles in chemical [18], electrochemical $[17,19]$ and sonoelectrochemical [10] syntheses.

The aim of the work is to research the sonoelectrochemical synthesis of silver nanoparticles in polyvinylpyrrolidone solutions using soluble anodes.

\section{Materials and research methods}

Sonoelectrochemical synthesis of colloidal solutions of silver nanoparticles was performed using a standard trielectrode electrochemical cell with a volume of $50 \mathrm{ml}$ and a MTech PGP-550M potentiostat. Two identical silver plates $\left(S=14.4 \mathrm{~cm}^{2}\right)$, during cyclic voltammetry, performed simultaneously the functions of working and auxiliary electrodes. The reference electrode was a silver chloride electrode $\mathrm{Ag} / \mathrm{AgCl}$ with a Luggin capillary containing $1 \mathrm{~mol} / \mathrm{L}$ $\mathrm{KNO}_{3}$. The studies of the electrochemical behavior of silver and the synthesis of AgNPs were carried out using cyclic voltammetry in PVP solutions with a concentration of $1-4 \mathrm{~g} / \mathrm{L} ; \mathrm{pH}=8,0 \ldots 9,5 ; \mathrm{t}=20 \ldots 60^{\circ} \mathrm{C}$. The potential sweep rate of CVA was $50 \mathrm{mV} / \mathrm{s}$ in the E range from +1.0 to $-1.0 \mathrm{~V}$.
For sonoelectrochemical synthesis of colloidal solutions of silver nanoparticles, an ultrasonic emitter of magnetostrictive type "Ultrasonic disintegrator" UD-20 (Poland) was used. The frequency of ultrasonic radiation was $22 \mathrm{kHz}$. Useful specific power of ultrasonic radiation was 40-62.5 W/L. Isothermal conditions for sonoelectrochemical synthesis of colloidal solutions of silver nanoparticles were provided by a UTU-4 ultrathermostat.

Theoretical calculations and processing of experimental data were performed using software (Inconico Screen Calipers 4.0, OriginPro 8.0).

\section{Results of that discussion}

$\mathrm{Ag}(+)$ ions form $[\mathrm{AgPVP}]^{+}$complexes in PVP solutions due to $\mathrm{O}-$ and $\mathrm{N}$-donor atoms in the surfactant molecule [20]. So, in cyclic voltammetry, the main electrochemical reactions can be represented as an algorithm that includes anodic dissolution of silver (6) and cathodic reduction of $\mathrm{Ag}(+)$ (7). Upon further reduction, $\mathrm{Ag}(0)$ atoms are combined into nanoclusters (AgNCs) and AgNPs, which are stabilized by polymer PVP molecules due to the formation of surface complexes of AgNCs $\leftarrow$ PVP та AgNPs $\leftarrow$ PVP.

$$
\begin{gathered}
\mathrm{Ag}+\mathrm{PVP}_{\mathrm{ads}} \rightarrow[\mathrm{AgPVP}]^{+}+\mathrm{e} \\
{[\mathrm{AgPVP}]^{+}+\mathrm{e} \rightarrow \mathrm{AgPVP}}
\end{gathered}
$$

The rate of electrode reactions $(6,7)$ increases significantly in the ultrasonic field. Thus, the values of anodic currents at $\mathrm{E}=1.0 \mathrm{~V}$ and cathodic currents at $\mathrm{E}=-0.5 \mathrm{~V}$ increase by $30-40 \%$ (Fig. 1).

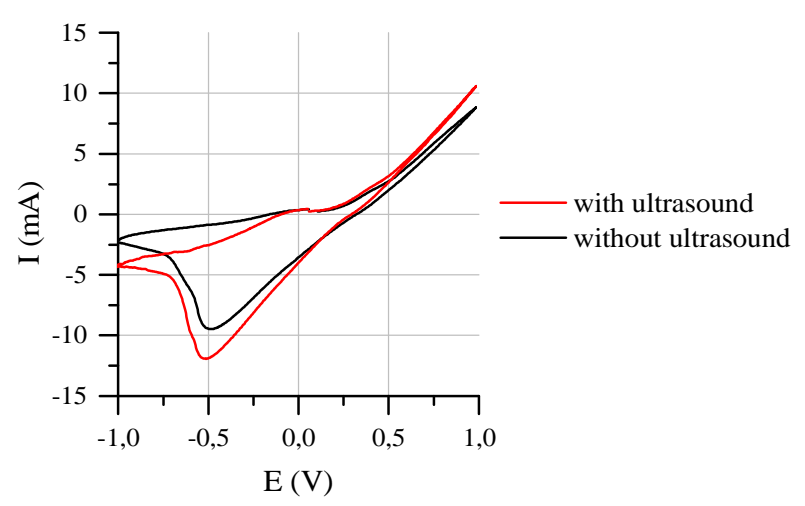

Fig. 1. CVA of redox processes of silver in PVP solution $(2 \mathrm{~g} / \mathrm{L})$ in the ultrasonic field and without it, $v=50 \mathrm{mV} / \mathrm{s}$, at 1 scan cycle

Such an effect of ultrasonic waves on electrochemical ones can be explained by the 
formation, growth and destruction of microbubbles in the electrolyte [21]. If cavitation occurs close to the electrode surface, the liquid jet penetrates into the bubble and perpendicular to the electrode surface. This leads to the formation of a high-speed microjet of liquid to the surface. When ultrasound exceeds the threshold intensity, the bubbles collapse is also caused by shock waves and microflows [1]. As a consequence, a decrease in the thickness of the diffusion layer accelerates mass transfer and, accordingly, electrode processes, and also promotes "degassing" of the electrode surface. The latter is important at high values of electrode potentials, when there are side processes of electrical evolution of hydrogen (at the cathode) and oxygen (at the anode), which are shield the surface. As mentioned earlier, under the action of ultrasonic cavitation, radicals $(2,3)$ are generated, which reduce $\mathrm{Ag}(+)$ ions in the volume of the solution $(4,5)$. So, AgNPs are formed during sonoelectrochemical synthesis due to electrochemical and chemical reduction of $\mathrm{Ag}(+)$ ions. The latter are formed due to the anodic dissolution of silver, therefore this electrochemical process is limiting. That's why the dependence of its rate on the main factors, namely the PVP concentration and temperature, actually defines the rate of sonoelectrochemical synthesis of AgNPs.

At sonoelectrochemical synthesis, the values of anodic currents decreases with increasing the PVP concentration (Fig. 2, a). Such an effect may be due to the increased adsorption of polar polymer molecules of surfactant on the surface of the silver electrodes during the anode period. This leads to an increase in the anodic polarization and, accordingly, inhibition of the electrochemical reaction (6). Since the latter is limiting in the algorithm of $\left.\left.\mathrm{Ag}(0)()^{\prime \prime} \rightarrow \operatorname{Ag}(+) ~\right)\right) \rightarrow$ $\mathrm{Ag}(0) \stackrel{\prime \prime}{\rightarrow}$ AgNPs, accordingly, the rate of sonoelectrochemical synthesis of nanoparticles slows down. This is confirmed by a decrease in optical density at $\lambda=400 \ldots 410 \mathrm{~nm}$ (Fig. $2, b$ ), which corresponds to AgNPs in PVP solutions [15-17]. However, the high concentration of stabilizer in solution promotes the formation of AgNP with an average size of 5-10 nm [10, 15-17]. So, the PVP concentration factor has a double effect that can be used to control the rate of sonoelectrochemical synthesis of AgNPs and their size.
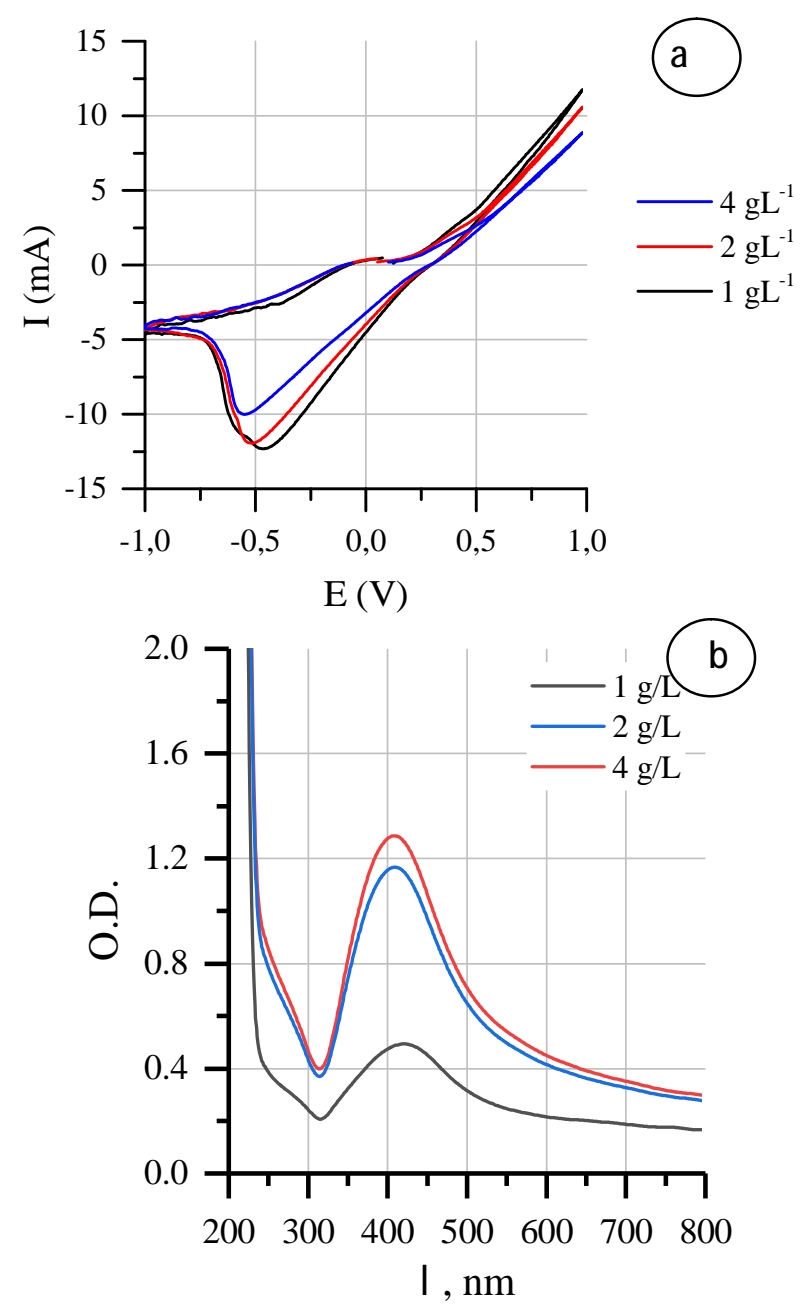

Fig. 2. CVA (a) and spectral dependences of optical absorption (b) of AgNPs, synthesized in PVP solution $(1,2,4 \mathrm{~g} / \mathrm{L})$ at $t=20^{\circ} \mathrm{C}, v=50 \mathrm{mV} / \mathrm{s}$ in ultrasonic field

The temperature at sonoelectrochemical synthesis of AgNPs in PVP solutions with the use of sacrificial anodes is primarily the rate factor of electrode processes (Fig. 3, a). However, the increase in the values of anodic currents, for example, at $\mathrm{E}=1.0 \mathrm{~V}$ in the range of $20 \ldots 60{ }^{\circ} \mathrm{C}$ is not high $-\sim 10 \%$ for every $10{ }^{\circ} \mathrm{C}$. This indicates the predominant diffusion nature of the temperature action. Obviously, the temperaturic rise of anode currents is also promotes by the desorption of PVP molecules from the anode surface. Accordingly, the the temperaturic rise of AgNPs synthesis rate is low (Fig. 3, b). After all, the limiting stage is the anodic dissolution of silver. Wherein, the value of the maximum varies little in the range of $20 \ldots 60{ }^{\circ} \mathrm{C}(\lambda=400 \ldots 410 \mathrm{~nm})$. This indicates that there is a slight change in the geometry of the nanoparticles and the size distribution. 

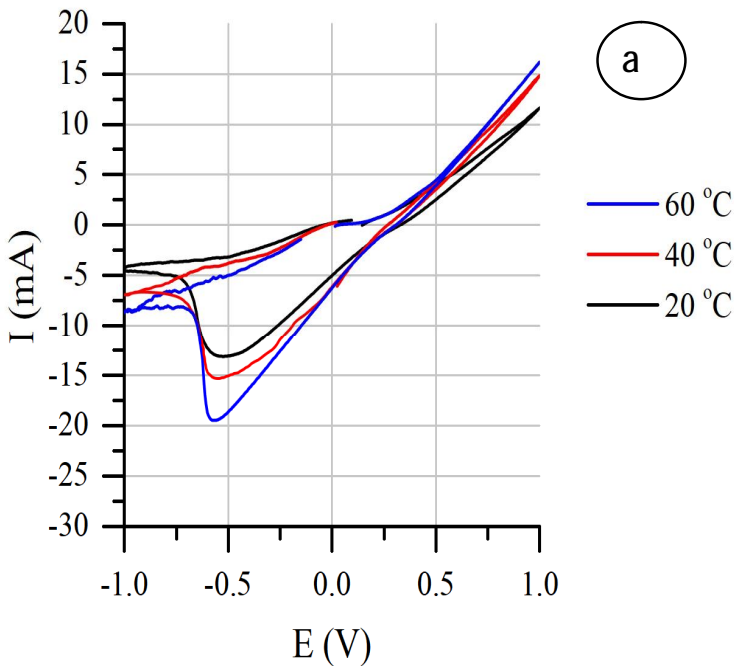

$-20{ }^{\circ} \mathrm{C}$

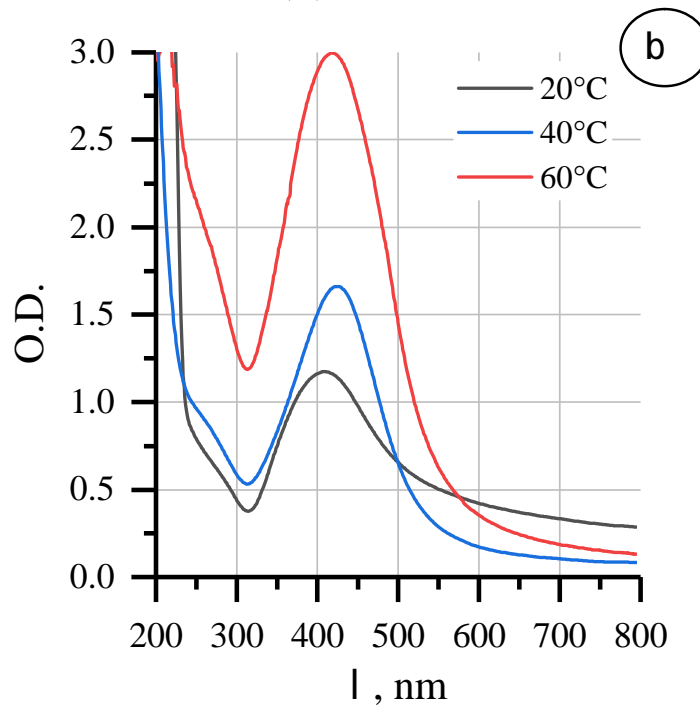

Fig. 3. CVA (a) and spectral dependences of optical absorption (b) of AgNPs, synthesized in PVP solution $(2 \mathrm{~g} / \mathrm{L})$ at $t=20-60^{\circ} \mathrm{C}, v=50 \mathrm{mV} / \mathrm{s}$

The character of CVA curves does not change during long-term sonoelectrochemical synthesis of AgNPs (Fig. 4, a). The deviation of the currents is insignificant, so, with an increase in the duration of electrolysis from 5 to $10 \mathrm{~min}$, the deviation is equal to 1.155 conventional units, from 10 to $15 \mathrm{~min}$. 1.380 , from 15 to $20 \mathrm{~min}$. - 2.113. Thus, it is constant during the synthesis, which provides a stationary electrolysis process. This indicates the stability of anodic processes and the technological possibility of using silver anodes in sonoelectrochemical synthesis of colloidal solutions of silver nanoparticles.

The increase in the concentration of AgNPs is also relatively stable (Fig. $4, b$ ). It is established that the optical density (OD) of AgNPs solutions increases almost linearly with increasing in the number of cycles. Wherein, the value of the absorption maximum remains within $400 \ldots 410 \mathrm{~nm}$.
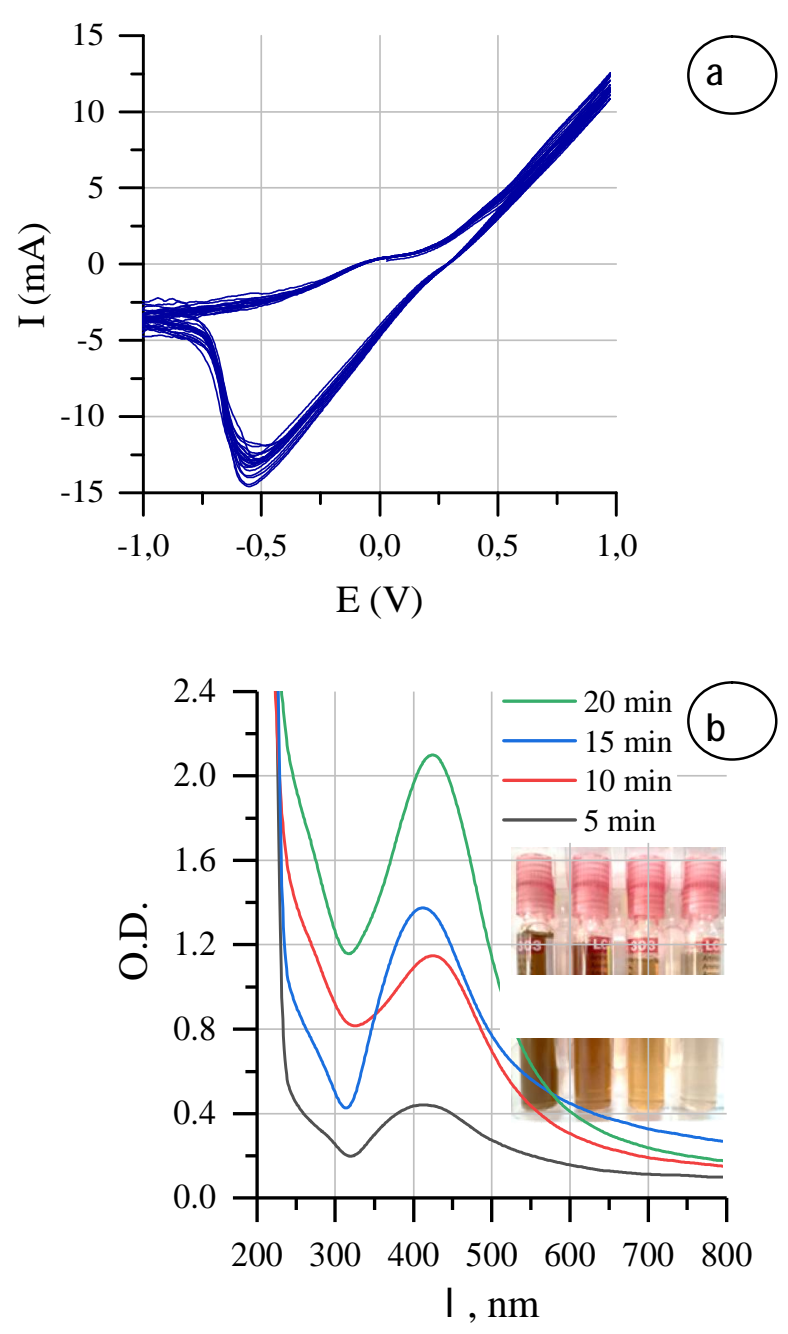

Fig. 4. CVA of silver in PVP solution $(2 \mathrm{~g} / \mathrm{L})(\mathrm{a})$ and spectral dependences of optical absorption of AgNPs, synthesized in ultrasonic field $(b), t=20^{\circ} \mathrm{C}$

\section{Conclusions}

The combination of cyclic voltammetry and ultrasonic field in polyvinypyrrolidone solutions with the use of sacrificial anodes creates conditions for their controlled synthesis of silver nanoparticles. In the potentials range from 0.2 to $1.0 \mathrm{~V}$ in $1-4 \mathrm{~g} / \mathrm{L}$ PVP solutions there is an active dissolution of silver with the formation of the $[\mathrm{AgPVP}]^{+}$soluble complex. The latter in the cathode period are restored with the formation of stabilized AgNPs, which provides an algorithm anodic formation of $\mathrm{Ag}$ ions(+) $\rightarrow$ cathodic reduction of $\mathrm{Ag}(+)$ to $\mathrm{Ag}(0)$. Compared with electrochemical, the rate of sonoelectrochemical synthesis of AgNPs is $30-40 \%$ higher. The latter 
factor indicates the predominant diffusion nature of the temperature. In this case, the latter factor indicates the prevailing diffuse nature of the temperature action. The increase in the concentration of AgNPs during long-term synthesis is relatively stable, which indicates the effectiveness of sacrificial anodes in sonoelectrochemical synthesis.

\section{Acknowledgment}

This work was carried out with the partial financial support of the National Research Foundation of Ukraine. Project registration number: 2020.02/0309 ("Design of polyfunctional nanostructured monoand bimetals with electrocatalytic and antimicrobial properties").

\section{References}

1. Birkin, P. R., Offin, D. G., Joseph, P. F., \& Leighton, T. G. (2005). Cavitation, shock waves and the invasive nature of sonoelectrochemistry. The Journal of Physical Chemistry B, 109(35), 16997-17005. https://doi.org/10.1021/jp051619w

2. Sáez, V., \& Mason, T. J. (2009). Sonoelectrochemical synthesis of nanoparticles. Molecules, 14(10), 4284-4299. https://doi.org/10.3390/molecules14104284

3. Sakkas, P., Schneider, O., Martens, S., Thanou, P., Sourkouni, G., \& Argirusis, C. (2012). Fundamental studies of sonoelectrochemical nanomaterials preparation. Journal of Applied Electrochemistry, 42(9), 763-777. https://doi.org/10.1007/s10800-012-0443-z

4. Hihn, J. Y., Doche, M. L., Hallez, L., Taouil, A. E., \& Pollet, B. G. (2018). Sonoelectrochemistry: both a tool for investigating mechanisms and for accelerating processes. The Electrochemical Society Interface, 27(3), 47.

https://doi.org/10.1149/2.F05183if

5. Islam, M. H., Paul, M. T., Burheim, O. S., \& Pollet, B. G. (2019). Recent developments in the sonoelectrochemical synthesis of nanomaterials. Ultrasonics sonochemistry, 59, 104711. https://doi.org/ 10.1016/j.ultsonch.2019.104711

6. Zhu, J., Liu, S., Palchik, O., Koltypin, Y., \& Gedanken, A. (2000). Shape-controlled synthesis of silver nanoparticles by pulse sonoelectrochemical methods. Langmuir, 16(16), 6396-6399. https://doi.org/ 10.1021/la991507u

7. Socol, Y., Abramson, O., Gedanken, A., Meshorer, Y., Berenstein, L., \& Zaban, A. (2002). Suspensive electrode formation in pulsed sonoelectrochemical synthesis of silver nanoparticles. Langmuir, 18(12), 47364740. https://doi.org/10.1021/la015689f

8. Jiang, L. P., Wang, A. N., Zhao, Y., Zhang, J. R., \& Zhu, J. J. (2004). A novel route for the preparation of monodisperse silver nanoparticles via a pulsed sonoelectrochemical technique. Inorganic Chemistry Communications, 7(4), 506-509. https://doi.org/10.1016/ j.inoche.2004.02.003

9. Liu, Y. C., \& Lin, L. H. (2004). New pathway for the synthesis of ultrafine silver nanoparticles from bulk silver substrates in aqueous solutions by sonoelectrochemical methods. Electrochemistry communications, 6(11), 11631168. https://doi.org/10.1016/j.elecom.2004.09.010

10. Tang, S., Meng, X., Lu, H., \& Zhu, S. (2009). PVP-assisted sonoelectrochemical growth of silver nanostructures with various shapes. Materials Chemistry and Physics, 116(2-3), 464-468. https://doi.org/10.1016/ j.matchemphys.2009.04.004

11. Kuntyi, O., Shepida, M., Sozanskyi, M., Sukhatskiy, Y., Mazur, A., Kytsya, A., \& Bazylyak, L. (2020). Sonoelectrochemical Synthesis of Silver Nanoparticles in Sodium Polyacrylate Solution, 11(4), 12202-12214. https://doi.org/10.33263/BRIAC114.1220212214

12. Pollet, B. G. (2010). The use of ultrasound for the fabrication of fuel cell materials. International Journal of Hydrogen Energy, 35(21), 11986-12004. https://doi.org/ 10.1016/j.ijhydene.2010.08.021

13. Cheon, J. Y., Kim, S. J., Rhee, Y. H., Kwon, O. H., \& Park, W. H. (2019). Shape-dependent antimicrobial activities of silver nanoparticles. International journal of nanomedicine, 14, 2773. https://doi.org/10.2147/IJN.S196472

14. Mozaffari, S., Li, W., Dixit, M., Seifert, S., Lee, B., Kovarik, L., ... \& Karim, A. M. (2019). The role of nanoparticle size and ligand coverage in size focusing of colloidal metal nanoparticles. Nanoscale Advances, 1(10), 4052-4066. https://doi.org/10.1039/C9NA00348G

15. Kuntyi, O. I., Kytsya, A. R., Mertsalo, I. P., Mazur, A. S., Zozula, G. I., Bazylyak, L. I., \& Topchak, R. V. (2019). Electrochemical synthesis of silver nanoparticles by reversible current in solutions of sodium polyacrylate. Colloid and Polymer Science, 297(5), 689-695. https://doi.org/10.1007/s00396-019-04488-4

16. Kuntyi, O., Mazur, A., Kytsya, A., Karpenko, O., Bazylyak, L., Mertsalo, I., \& Prokopalo, A. (2020). Electrochemical synthesis of silver nanoparticles in solutions of rhamnolipid. Micro \& Nano Letters, 15(12), 802-807. https://doi.org/10.1049/mnl.2020.0195

17. Kuntyi, O. I., Kytsya, A. R., Bondarenko, A. B., Mazur, A. S., Mertsalo, I. P., \& Bazylyak, L. I. (2021). Microplasma synthesis of silver nanoparticles in PVP solutions using sacrificial silver anodes. Colloid and Polymer Science, 1-9. https://doi.org/10.1007/s00396021-04811-y

18. Malina, D., Sobczak-Kupiec, A., Wzorek, Z., \& Kowalski, Z. (2012). Silver nanoparticles synthesis with different concentrations of polyvinylpyrrolidone. Digest Journal of Nanomaterials \& Biostructures, 7(4). 


\section{Sonoelectrochemical synthesis of silver nanoparticles in polyvinylpyrrolidone solutions}

19. Yin, B., Ma, H., Wang, S., \& Chen, S. (2003). Electrochemical synthesis of silver nanoparticles under protection of poly (N-vinylpyrrolidone). The Journal of Physical Chemistry B, 107(34), 8898-8904.

https://doi.org/10.1021/jp0349031

20. Zhang, Z., Zhao, B., \& Hu, L. (1996). PVP protective mechanism of ultrafine silver powder synthesized by chemical reduction processes. Journal of
Solid State Chemistry, 121(1), 105-110. https://doi.org/ 10.1006/jssc.1996.0015

21. Okitsu, K., \& Cavalieri, F. (2018). Synthesis of metal nanomaterials with chemical and physical effects of ultrasound and acoustic cavitation. In Sonochemical Production of Nanomaterials, pp. 1937. Springer, Cham. https://doi.org/10.1007/978-3-31996734-9_2

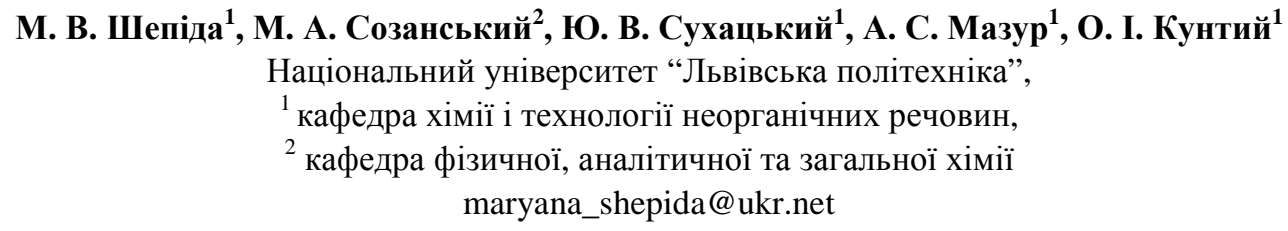

\section{СОНОЕЛЕКТРОХІМІЧНИЙ СИНТЕЗ НАНОЧАСТИНОК СРІБЛА У РОЗЧИНАХ ПОЛІВІНІЛПІРОЛІДОНУ}

Наведено результати досліджень впливу головних параметрів (концентрації ПАР і температури) на синтез наночастинок срібла (AgNPs) соноелектрохімічним методом у розчинах полівінілпіролідону (PVP) за циклічної вольтрамперометрії (CVA). Показано, що ультразвукове поле (22 kНz) спричиняє зростання анодних і катодних струмів на - 30 \%. Запропоновано схему утворення AgNPs iз такими основними процесами: 1) розчинення жертовних срібних анодів за $\mathbf{E}=\mathbf{0 . 2 . . 1 . 0} \mathrm{V}$ утворенням комплексного йона $[\mathrm{AgPVP}]^{+}$; 2) катодне й сонохімічне відновлення останнього до $\mathrm{Ag}(0)$; 3) формування AgNPs. Встановлено, що з підвищенням концентрації PVP від 1 до 4 g· $\mathrm{L}^{-1}$ анодні та катодні струми зменшуються на 40-60 \%. Зменшусться також швидкість утворення AgNPs. Зростання анодних і катодних струмів і швидкості формування наночастинок у діапазоні $20-60{ }^{\circ} \mathrm{C}$ відповідає дифузійно-кінетичній дії температурного фактора. CVA криві практично не змінються в часі, що свідчить про стабільність анодних і катодних процесів за тривалого соноелектрохімічного синтезу. Характер UV-Vis колоїдних розчинів AgNPs y PVP із максимумом поглинання 405-410 нм однаковий у широкому діапазоні концентрацій наночастинок.

Ключові слова: соноелектрохімічний синтез; наночастинки срібла; полівінілпіролідон; жертовні аноди; циклічна вольтамперометрія; “зелений” синтез. 